\title{
Co-treatment Effect of Syzygium cumini (L.) Skeels on Indomethacin Induced Gastric Ulcer on Mice Model $^{\dagger}$
}

\author{
Montakarn THONGSOM ${ }^{1}$, Lanchakon CHANUDOM ${ }^{1}$ and \\ Jitbanjong TANGPONG, ${ }^{2, *}$
}

${ }^{I}$ Faculty of Science and Technology, Nakhonsithammarat Rajabhat University, Nakhon Si Thammarat 80280, Thailand

${ }^{2}$ Research Excellence Center for Innovation and Health Product and Biomedical Sciences, School of Allied Health Sciences, Walailak University, Nakhon Si Thammarat 80161, Thailand

("Corresponding author's email: njibjoy@yahoo.com)

Received: 31 March 2018, Revised: 11 September 2018, Accepted: 7 October 2018

\begin{abstract}
Syzygium cumini (L.) Skeels or SCC originally from India and Southeast Asia, commonly used as a medicinal and acted as antioxidant and anti-inflammatory plant. Indomethacin, which is a part of nonsteroidal anti-inflammatory drugs (NSAIDs) family, induced gastric damage and perforation through the excess generation of reactive oxygen species (ROS). This research focus on co-treatment administered between SCC and indomethacin in the subsequent 7 days and evaluated on oxidative damage, inflammatory parameter and epidermal growth factor (EGF) receptor. SCC showed a concentration and dose dependent reduction in ulcer index (UI) values leading to the increasing of inhibition percent when compared to indomethacin treated mice, confirmed by photographer which showed maximum efficacy on day 5 of treatment. On day 1 and day 3 of ulceration, malondialdehyde (MDA), oxidized glutathione (GSSG), nitrile contents and tumor necrosis factor-alpha (TNF- $\alpha$ ) were increased. Gastric wall mucus and glutathione peroxidase (GPx) were down. After that gastric mucosa were recovered by healing processed and were regenerated the mucosal cap to promote EGF receptor. SCC was increased the up-regulation of COX-1 enzyme resulting in down-regulation to COX-2 expression at day 3 of ulceration. At day 5 and 7 , the gastric ulceration were regenerated themselves. These all results indicated that SCC have a great protective effect against indomethacin induced gastric ulcer in in-vivo co-treatment model.
\end{abstract}

Keywords: Co-treatment, Syzygium cumini (L.) Skeels, indomethacin, gastric ulcer and mice model

\section{Introduction}

The lifetime risk for developing a gastric ulcer is approximately $10 \%$. It can develop more than 1 time in the lifetime of a man. It is quite common and developed in about half a million people each year in the United States and can be expected to develop in $5-10 \%$ of the adult population during the lifetime in Western countries [1-3]. Nonsteroidal anti-inflammatory drugs (NSAIDs) are among the most commonly used drugs worldwide due to their analgesics, anti-inflammatory and anti-pyretic therapeutic properties [4,5]. More than 30 million people use NSAIDs every day, and they account for $60 \%$ of the US over the counter analgesic market [4,6]. Indomethacin is a NSAID that also has anti-pyretic, antithrombotic and analgesic effects [7]. Its most common side effect is gastrointestinal tract damage, such as stomach ulcers [8]. Several pharmacological agents, antioxidants and plant extracts have been

\footnotetext{
${ }^{\dagger}$ Presented at the International Conference on Biomedical Sciences 2018: March 22 ${ }^{\text {nd }}-23^{\text {rd }}, 2018$
} 
used to protect against gastric damage, and successful results have been obtained [9-11] and Syzygium cumini (L.) Skeels or SCC is one of it. SCC, belongs to the Myrtaceae family. Its bark, leaves, fruits and seeds are prepared and administered in different ways according to their properties such as potential antidiabetic action [12], antioxidant [13], antimicrobial [14], anti-inflammatory [15], anthelmintic, antifungal, diuretic and anti-diarrheal [16]. The main compounds of the plant that gives these all properties is the high content of flavonoids [17]. Eighty two \% of the essential oils present in the plant is gallic acid, kaempferol, myricetin, ellagic acid, chlorogenic acid, quercetin, rutin, anthocyanins and tannins $[16,18]$.

On the model of indomethacin induced acute gastric ulceration, SCC caused discernible decrease gastric lesion and lipid peroxide content and also restored oxidized gluthathione (GSSG), glutathione peroxidase (GPx), nitric oxide (NO) levels and gastric wall mucus. Indomethacin induced inflammation by activated inducible nitric oxide synthase (iNOS) and tumor necrosis factor-alpha (TNF- $\alpha$ ) [15]. However, in the long term of indomethacin usage still have less in literature. Therefore, this research was aimed to consider the SCC co-treatment with indomethacin in the subsequent 7 days on oxidative stress and inflammatory parameter. Thus, our experiment will provide some baseline information which may highlight the potential of SCC as a gastric ulceration inhibitor.

\section{Materials and methods}

\section{Plants}

Syzygium cumini (L.) Skeels was collected from various areas at Nakhon Si Thammarat province, Thailand. To prepare an aqueous leaf extracts, young fresh leaves were rinsed with distilled water, chopped and homogenized into distilled water in a blender for $1 \mathrm{~min}$. The suspension was filtered and lyophilized by freeze dryer at $-20{ }^{\circ} \mathrm{C}$ for $20 \mathrm{~h}$. The powder of Syzygium cumini (L.) Skeels aqueous crude extract (SCC) was kept at $-30^{\circ} \mathrm{C}$ for until used.

\section{The effect of SCC on indomethacin induced gastric ulcer in vivo Animals}

Mice were bred at Mahidol University, Bangkok, Thailand and were procured after obtaining clearance from the respective Animal Committee of the Walailak University, Thailand. Mice were handled following International Animal Ethics Committee Guidelines. Male mice $(30-40 \mathrm{gBW}$ at 5 weeks old) were kept in controlled environment, at a constant temperature $\left(23 \pm 2{ }^{\circ} \mathrm{C}\right)$ and humidity $(60 \pm 10 \%)$, and a $12 \mathrm{~h} \mathrm{light/dark} \mathrm{cycle.} \mathrm{Mice} \mathrm{were} \mathrm{acclimatized} \mathrm{for} \mathrm{one} \mathrm{week} \mathrm{before} \mathrm{any} \mathrm{experimental}$ procedures and were allowed standard rat chow and tap water ad libitum.

\section{Co-treatment effect of SCC on indomethacin induced gastric ulcer}

Male mice were divided into 7 groups $(n=6)$ and orally treated as follows:

Group 1: Untreated control (phosphate buffer solution: PBS),

Group 2: PBS + indomethacin $(10 \mathrm{mg} / \mathrm{kgBW})$,

Group 3: SCC (100 mg/kgBW) + indomethacin $(10 \mathrm{mg} / \mathrm{kgBW})$,

Group 4: SCC (250 mg/kgBW) + indomethacin $(10 \mathrm{mg} / \mathrm{kgBW})$,

Group 5: SCC (500 mg/kgBW) + indomethacin (10 mg/kgBW),

Group 6: omeprazole $(100 \mathrm{mg} / \mathrm{kgBW})+$ indomethacin $(10 \mathrm{mg} / \mathrm{kgBW})$,

Group 7: vitamin C $(100 \mathrm{mg} / \mathrm{kgBW})+$ indomethacin $(10 \mathrm{mg} / \mathrm{kgBW})$.

Ten $\mathrm{mg} / \mathrm{kgBW}$ of indomethacin treated in group 2 to group 7 was suspended in an aqueous solution of sodium bicarbonate (5\%) and was administered after one hour of PBS, SCC, omeprazole and vitamin $\mathrm{C}$ pretreatment. The mice of all groups were orally treated as follows at the same time for 7 days.

Four hour after administering the last dose of the test samples on each sampling day $(1,3,5$ and 7 days), the stomachs of mice were removed. The ulcerated portions of the stomach were sectioned after fixing in $10 \%$ formal saline solution. After $24 \mathrm{~h}$ of fixation followed by embedding in a paraffin block, it was cut into sections of $5 \mu \mathrm{m}$ onto a glass slide, stained with haematoxylin-eosin and the histology examined under a light microscope. The damage scores, biochemical parameter, cyclooxygenase 1 and 2 
(COX-1 and COX-2), inducible nitric oxide synthase (iNOS), Tumor necrosis factor-alpha (TNF- $\alpha$ ) and epidermal growth factor (EGF) receptor of untreated and treated mice was measured.

The gastric ulcer was evaluated by measurement the length of ulcer in mm. scale. Ulcer index (UI) was calculated from the total of gastric ulcer area $(\mathrm{mm})$ divided with total mice in each group. Inhibition percent ( $\%$ inhibition) was calculated follow the formula;

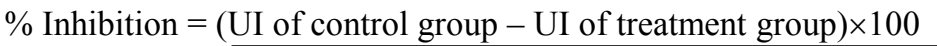

The mucus bound to the epithelial surface ( $\mu \mathrm{g} / \mathrm{g}$ tissue) was performed according to the method of Corne et al. [19].

\section{Determination of oxidative damage}

Determination of lipid peroxides

Gastric mucosal was homogenized with $1 \%(\mathrm{v} / \mathrm{v})$ orthophosphoric acid and $0.6 \%(\mathrm{w} / \mathrm{v})$ thiobarbituric acid, then boiled for $45 \mathrm{~min}$ at $100{ }^{\circ} \mathrm{C}$. After cooling, the colored product was extracted by n-butanol, vortexed and centrifuged at $3000 \mathrm{~g}$ for $15 \mathrm{~min}$. The absorbance of the upper layer was read spectrophotometerically at 535 and $520 \mathrm{~nm}$. The difference in absorbance was calculated as gastric mucosal lipid peroxides level and expressed as nmol/g tissue malondialdehyde [20].

\section{Determination of oxidized glutathione (GSSG)}

The gastric tissue was homogenized and diluted to 10 folds, $10 \mu 1$ of EDTA and $10 \mu \mathrm{l}$ of NADPH were added. Mixed and recorded the baseline level of NADPH absorbance. For measurement of standard GSSG solution, $1 \mathrm{ml}$ sample was replaced by $1 \mathrm{ml}$ buffer and standard GSSG at volume containing 5 nmol. The oxidized glutathione levels were present as $\mathrm{ng} / \mathrm{mg}$ protein [21].

\section{Determination of glutathione peroxidase (GPx)}

The activity was expressed as $\mathrm{U} / \mathrm{g}$ protein following the reaction mixture consisted of $100 \mu \mathrm{l}$ of buffer, $20 \mu \mathrm{l}$ of GSH, $100 \mu \mathrm{l}$ of GR, $100 \mu \mathrm{l}$ of NADPH, $10 \mu \mathrm{l}$ of homogenated gastric tissue, $10 \mu \mathrm{l}$ of $\mathrm{NaN}_{3}$ and $660 \mu \mathrm{l}$ of distilled water. This mixture was warmed at $37{ }^{\circ} \mathrm{C}$ for $10 \mathrm{~min}$ and then $10 \mu \mathrm{l}$ of tbutyl hydroperoxide was added. The OD at $340 \mathrm{~nm}$ was then followed. A blank value was obtained without any addition of substrates was subtracted from the assay values. The activity of glutathione peroxidase was calculated from the change in optical density in $1 \mathrm{~min}$ and the molar extinction coefficient for NADPH at $340 \mathrm{~nm}$ of $6.22 \mathrm{nM} / \mathrm{cm}$. Protein (mg/g tissue) was determined by Lowry et al. [22] method.

\section{Determination of nitric oxide level}

Nitric oxide (nmol/g tissue) were examined indirectly as nitrite/nitrate concentration using Griess reaction-dependent method [23]. Gastric mucosal homogenates were deproteinated with absolute ethanol for $48 \mathrm{~h}$ at $4{ }^{\circ} \mathrm{C}$, centrifuged at $12000 \mathrm{~g}$ for $15 \mathrm{~min}$ at $4{ }^{\circ} \mathrm{C}$. An aliquot of the supernatant vanadium trichloride $0.8 \%(\mathrm{w} / \mathrm{v})$ in $1 \mathrm{M} \mathrm{HCl}$ was added for the reduction of nitrate to nitrite, followed by the rapid addition Griess reagent consisting of $0.1 \%(\mathrm{w} / \mathrm{v}) \mathrm{N}-(1-\mathrm{Naphthyl})$ ethylenediamine dihydrochloride and 2 $\%(\mathrm{w} / \mathrm{v})$ sulfanilamide in $5 \%(\mathrm{v} / \mathrm{v}) \mathrm{HCl}$ and incubated for $30 \mathrm{~min}$ at $37{ }^{\circ} \mathrm{C}$. Mixtures were cooled and read at $540 \mathrm{~nm}$ was measured.

\section{Determination of inflammatory parameter}

Tumor necrosis factor-alpha (TNF-a) assay

The plasma samples were collected from the mice. Each sample was incubated with TNF- $\alpha$ detection antibody solution while shaking for $1 \mathrm{~h}$. Samples were discarded and washed 4 times with assay buffer and conjugated with avidin-HRP A solution for $30 \mathrm{~min}$ while shaking finally, discard and washed to minimize background. One hundred $\mu \mathrm{l}$ of substrate solution F was added and incubated for $15 \mathrm{~min}$ in 
the dark to form a complex with a stabilized chromogen. The reaction was stop by adding $100 \mu$ of stop solution to get yellow color. Absorbance was read at $450 \mathrm{~nm}$ within $30 \mathrm{~min}$ and subtracted with the absorbance at $570 \mathrm{~nm}$.

\section{Western blot technique for COX-1, COX-2 and iNOS expression}

The gastric mucosa was washed with PBS containing protease inhibitors, minced and homogenized in a PBS buffer containing protease inhibitor. After centrifugation at $14,000 \mathrm{~g}$ for $20 \mathrm{~min}$ at $4{ }^{\circ} \mathrm{C}$, the supernatant were collected, aliquoted, and kept at $-80^{\circ} \mathrm{C}$ before use in the western blots. The proteins were resolved by SDS-polyacrylamide gel electrophoresis and transferred to a nitrocellulose membrane. The membrane was blocked for $1 \mathrm{~h}$ in Tris-buffered saline with Tween 20 (TBST) $(20 \mathrm{mM}$ Tris- $\mathrm{HCl}, \mathrm{pH}$ $7.4,150 \mathrm{mM} \mathrm{NaCl}, 0.02 \%$ Tween 20 ) containing $5 \%$ bovine serum albumin or skim milk and incubated overnight at $4{ }^{\circ} \mathrm{C}$ with the appropriate primary antibody. The membrane was washed with TBST twice for $7 \mathrm{~min}$ and Tris-buffered saline (TBS). Then membrane was incubated with the appropriate peroxidase conjugated secondary antibody. The bands were detected using an enhanced chemiluminescence detection kit and quantified with respect to the bands of a suitable loading control, using the Kodak Gelquant software [24].

\section{EGF receptor assay}

The immunostaining of EGF receptor was carried out with minor modifications. In this case, after blocking the endogenous peroxidase and treatment with the protein blockers, the tissue sections were incubated overnight at $4{ }^{\circ} \mathrm{C}$ with primary antibody (mouse polyclonal, 1:200). The peroxidase conjugated goat anti-mouse $\operatorname{IgG}(1: 500)$ was used as the secondary antibody. Excess secondary antibodies were removed by washing three times in PBS and once with deionized $\mathrm{H}_{2} \mathrm{O}$. Tissue slides were counter staining with nuclear staining dye (DRAQ5) and mounted with mounting medium. Photomicrographs were obtained using a Leica confocal fluorescence microscope.

\section{Statistical analysis}

All statistical analyses were run in triplicate. Data obtained was expressed as mean \pm standard error of mean (SEM). Parameter data of all the biochemical parameters were analyzed using one-way analysis of variance (ANOVA) followed by the Student-Newman-Keuls test. A probability values of $P<0.05$ were considered statistically significant.

\section{Results and discussion}

The effect of SCC on ulcer index (UI) and inhibition percent on co-treatment study

Table 1 was shown an UI values on co-treatment experiment. The mice receiving PBS (g.1) was not show any lesions in the gastric mucosa while the treated mice with indomethacin (g.2-7) produced typical time dependent mucosal lesions in terms of UI values. Mice treated with indomethacin was the highest and showed significant increase in UI values at $66.67 \pm 15.44$ and $69.69 \pm 18.68$ at day 1 and day 3 , respectively when compared with untreated control group. On day 5 and day 7, the area of indomethacin treated groups were progressive recovery and reduced the UI values to $57.78 \pm 27.99$ and $48.89 \pm 13.11$, respectively.

The UI values of SCC treated groups at 100,250 and $500 \mathrm{mg} / \mathrm{kgBW}$ were $60.00 \pm 19.02$, $69.69 \pm 18.68$ and $57.78 \pm 27.99$, respectively at the first day of ulceration. On day 3 of experiment, UI values were $61.27 \pm 30.93,60 \pm 7.72$ and $47.22 \pm 7.18$, respectively. The UI values were reduced to $48.83 \pm 16.54,45.24 \pm 10.80$ and $40.63 \pm 6.87$, respectively at day 5 and were $42.5 \pm 8.53,38.89 \pm 11.55$ and $33.79 \pm 4.81$, respectively at day 7 . Treated mice with SCC showed a concentration and dose-dependent reduction in UI values compared to indomethacin treated mice of the corresponding days.

The inhibition percent of gastric ulcers were calculated and the results showed that inhibition percent of gastric ulcer showed no significant difference in the group of indomethacin treated mice on day 1 and day 3. As well known, the mucosal were natural restored and the inhibition percent of gastric ulcer showed significantly increase to $13.34 \pm 9.69$ and $29.67 \pm 11.34 \%$, respectively in day 5 and day 7 . 
http://wjst.wu.ac.th

Treatment with SCC increased inhibition percent as dose dependent manner and at the dose 500 $\mathrm{mg} / \mathrm{kgBW}$ showed $49.31 \pm 1.41 \%$ and showed the greater protective action than in omeprazole and vitamin $\mathrm{C}$ treated mice (Table $\mathbf{1}$ ).

\section{Pathology and histopathology of gastric tissue of SCC prevent gastric ulceration by co- treatment treated}

Ulcer healing is a complex process involving various factors. The gastro-toxicity of the NSAIDs including indomethacin in animals can be attributed to their ability to induce the reactive oxygen metabolites [25]. They also delay ulcer healing by reducing the prostaglandin level [26] and preventing the prostaglandin mediated angiogenesis. After haemorrhagic ulcer, re-epithelialization process are occur by forming a mucoid cap and also the growth factors and their receptors such as EGF receptor assist in ulcer healing by potential angiogenesis, and increasing the release of gastric mucin. SCC was arrested ulcer progression by antioxidant action due to powerful in vitro antioxidant property. Photograph of gastric tissue (Figure 1) and histopathological examinations (photograph not shown) revealed that administration of indomethacin at $10 \mathrm{mg} / \mathrm{kgBW}$ caused marked damage to the gastric mucosa within one day, with elongated haemorrhagic lesions, confined to the glandular portion. Maximum ulcerative damage was observed on the day 3 after administration of indomethacin and the nature of ulceration was evident from natural recovery (autohealing) of the gastric tissues even without any treatment.

In comparison, the mice treated with SCC at $500 \mathrm{mg} / \mathrm{kgBW}$ showed significant greater and faster in wool healing within 3 days. However, on the day 7 of ulceration, the natural recovery itself was substantial and the beneficial effect of the test samples was not very important. Overall, SCC (at highest dose) showed maximum efficacy on day 5 of treatment. SCC was similarly effective on gastro-protection and the qualitative histopathological assessment also correlated well with these data.

Determination of malondialdehyde (MDA) in plasma and tissue of co-treatment study

Compared to the normal mice, the content of thiobarbituric acid reactive substances of indomethacin treated mice was elevated to $15.50 \pm 0.91$ and $19.71 \pm 1.38 \mathrm{nM} / \mathrm{ml}$ respectively on day 1 and day 3 of ulceration in plasma samples. Treatment of SCC, omeprazole or vitamin $\mathrm{C}$ showed immediate effect significantly reducing the MDA from day 1 of ulceration $(P<0.05)$ and the highest MDA levels were found on day 3 of ulceration. At day 3, SCC at concentration of $100-500 \mathrm{mg} / \mathrm{kgBW}$ reduced MDA levels to $14.33 \pm 0.59,11.88 \pm 0.65$ and $3.38 \pm 0.46 \mathrm{nM} / \mathrm{ml}$ respectively. Omeprazole or vitamin $\mathrm{C}$ at 100 $\mathrm{mg} / \mathrm{kgBW}$ was decreased MDA level to $3.83 \pm 0.34$ and $8.96 \pm 0.68 \mathrm{nM} / \mathrm{ml}$ compared to indomethacin treated group at day 3 of ulceration. After day 7 of ulceration, MDA level of all groups were significantly reduced when compared to indomethacin treated group and remained almost similar to normal level. The MDA level in plasma of SCC $(100-500 \mathrm{mg} / \mathrm{kgBW})$, omeprazole or vitamin C was $7.45 \pm 1.69,4.08 \pm 0.77$, $3.32 \pm 0.55,3.42 \pm 0.39$ and $4.04 \pm 0.79 \mathrm{nM} / \mathrm{ml}$, respectively at day 7 of ulceration.

The MDA levels in gastric tissues were demonstrated in table 1. The MDA levels of indomethacin treated mice were significantly increased to $5.91 \pm 0.30$ and $7.19 \pm 0.27 \mathrm{nM} / \mathrm{mg}$ protein of day 1 and day 3 of ulceration $(P<0.05)$ and were continuously reduced until the last day of ulceration by natural wool healing process. study

Determination of gastric wall mucus on indomethacin-induced gastric ulcer of co-treatment

Treatment with indomethacin at $10 \mathrm{mg} / \mathrm{kgBW}$ was rapidly decreased mucin secretion when compared to normal mice at day 1 and was lowest decreased at day 3 of ulceration at $10.38 \pm 1.89 \mu \mathrm{g}$ Alcian blue/g wet stomach. Ulceration by indomethacin might reduce the ability of the mucosal membrane to protect the mucosa from pathological damage and back diffusion of hydrogen ions [25]. However, at day 5 and 7 of ulceration gastric mucosa were recovered by healing processed and was regenerated the mucosal cap to promote epithelial mucus, then the gastric wall mucus increased to $12.87 \pm 2.35$ and $15.73 \pm 0.24 \mu \mathrm{g}$ Alcian blue/g wet stomach, respectively as shown in Table $\mathbf{1}$.

The gastric wall mucus in SCC at $500 \mathrm{mg} / \mathrm{kgBW}$ treated group was also reduced from normal level, but significantly increased compared to indomethacin treated mice $(P<0.05)$. The reduction of gastric 
http://wjst.wu.ac.th

wall mucus at day 3 of this SCC treated group was at $22.06 \pm 0.51 \mu \mathrm{g}$ Alcian blue $/ \mathrm{g}$ wet stomach. After day 5 and day 7 of ulceration the gastric wall mucus levels were increased to $30.35 \pm 0.26$ and $32.89 \pm 0.50$ $\mu \mathrm{g}$ Alcian blue/g wet stomach, respectively. Omeprazole and vitamin $\mathrm{C}$ treated group, gastric wall mucus levels were reduced at day 3 and were recovered at day 5 and day 7 of ulceration. An increase in mucus production usually associated with an increase in the mucus layer in the gastric mucosal. Amongst the test samples, SCC restored the mucus level maximum, which was even better that omeprazole treated group.

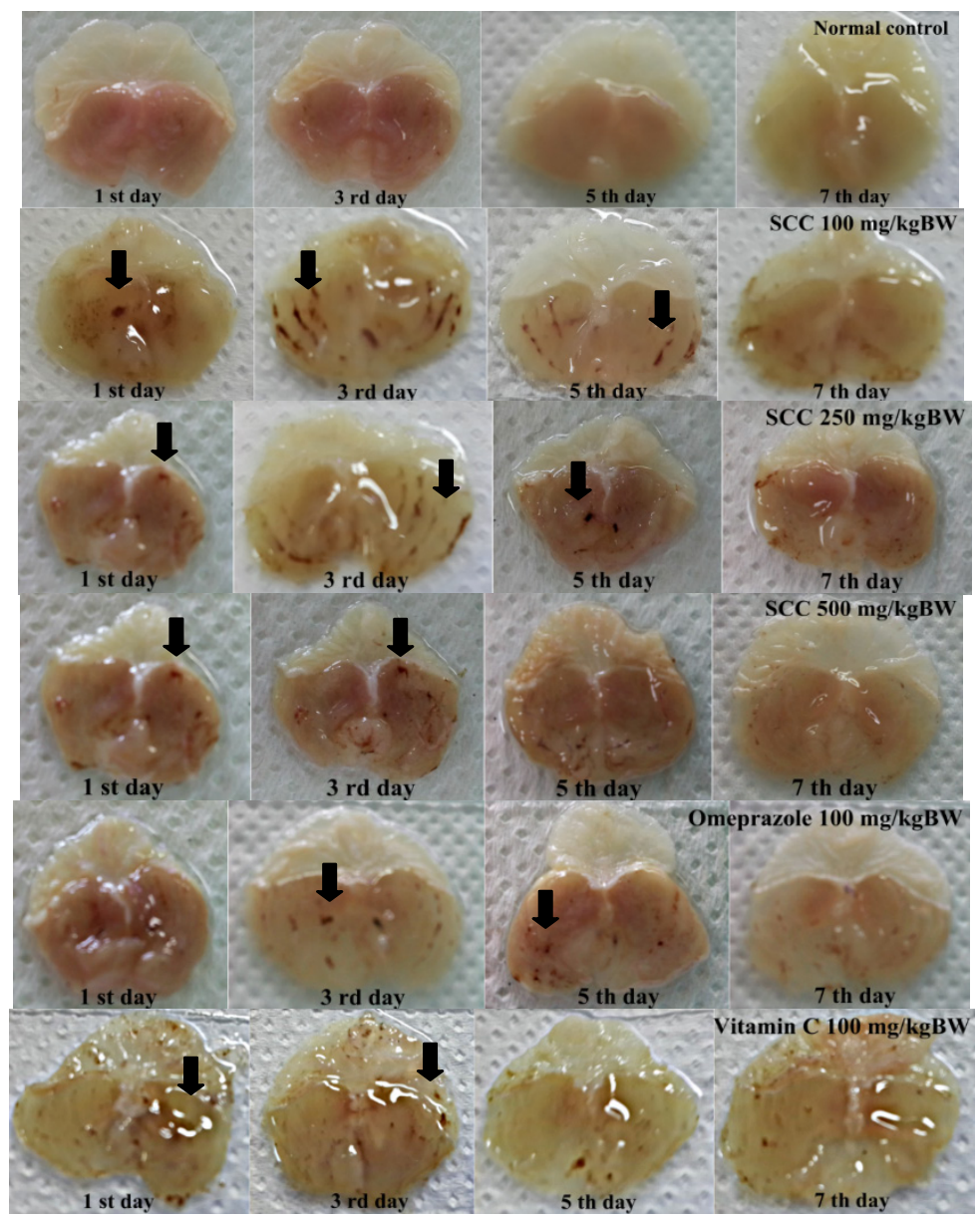

Figure 1 Photograph of protective effect of SCC on gastric tissue after induced with $10 \mathrm{mg} / \mathrm{kgBW}$ of indomethacin on day $1,3,5$ and 7 . Black arrow represented the ulcer area in gastric tissue.

\section{Antioxidant effect of SCC in indomethacin induce gastric ulcer of co-treatment study \\ Effect on oxidized glutathione (GSSG)}

GSSG level of indomethacin treated mice was higher increased than the other group at the same day of ulceration. The maximum GSSG level of indomethacin treated mice was found on day 3 and the level of GSSG were decreased after day 5 and 7 of ulceration. Treatment with SCC at all concentrations, omprazole or vitamin C were significantly increased the GSSG level from day 1 to day 3 of ulceration and the highest level of GSSG are occurred on day 3. However, GSSG levels of SCC treated mice were 
significantly reduced when compared to indomethacin group. SCC at $500 \mathrm{mg} / \mathrm{kgBW}$ was shown the great reduction on GSSG level after day 7 of ulceration.

\section{Effect on glutathione peroxidase (GPX)}

The activity of GPx enzyme was rapidly reduced in all treated mice from day 1 to day 3 of ulceration. After day 5 the recovery processes of gastro endothelial was adapted defense response to mucosa injury. Therefore, the GPx activity was increased in all treated group after day 5. In comparison to indomethacin treated mice, treatment with SCC at all concentration, omeprazole or vitamin $\mathrm{C}$ were increased the activities of GPx at the same day of ulceration. On day 7 of experiment, SCC at a concentration of $500 \mathrm{mg} / \mathrm{kgBW}$ was maintained the GPx enzyme activity to the basal level compared to normal mice.

\section{Effect on nitrile contents}

Nitrile contents of indomethacin treated group were significantly increased from day 1 to day 5 of ulceration compared to normal control. The highest level of nitrile was found on day 5 of ulceration at $3.16 \pm 0.42 \mathrm{nM} / \mathrm{mg}$ protein. All treated compounds (SCC, omeprazole or vitamin C) were significantly reduced the nitrile contents when compared to indomethacin treated mice at the same day of ulceration. The highest effective of treated compound is SCC at a concentration of $500 \mathrm{mg} / \mathrm{kgBW}$, which was reduced the nitrile contents to $0.47 \pm 0.09 \mathrm{nM} / \mathrm{mg}$ protein at the last day of ulceration.

Table 1 Ulcer index, inhibition percent, malondialdehyde (MDA), mucus, oxidized glutathione (GSSG), glutathione peroxidase (GPx), nitrite contents and TNF- $\alpha$ on SCC co-treatment study in mice.

\begin{tabular}{|c|c|c|c|c|c|c|c|c|}
\hline Parameter & Day & Group 1 & Group 2 & Group 3 & Group 4 & Group 5 & Group 6 & Group 7 \\
\hline \multirow{4}{*}{ Ulcer index } & 1 & - & $66.67 \pm 15.44^{\mathrm{a}}$ & $60.00 \pm 19.02^{\mathrm{a}}$ & $58.88 \pm 7.22^{\mathrm{a}}$ & $48.12 \pm 15.58^{\mathrm{a}}$ & $57.42 \pm 7.17^{\mathrm{a}}$ & $62.34 \pm 7.52^{\mathrm{a}}$ \\
\hline & 3 & - & $69.69 \pm 18.68^{\mathrm{a}}$ & $61.27 \pm 30.93^{\mathrm{a}}$ & $60.00 \pm 7.72^{\mathrm{a}}$ & $47.22 \pm 7.18^{\mathrm{a}, \mathrm{c}}$ & $62.91 \pm 8.11^{\mathrm{a}}$ & $64.47 \pm 5.54^{\mathrm{a}}$ \\
\hline & 5 & - & $57.78 \pm 27.99^{\mathrm{a}}$ & $48.83 \pm 16.54^{\mathrm{a}}$ & $45.24 \pm 10.80^{\mathrm{a}}$ & $40.63 \pm 6.84^{\mathrm{a}}$ & $41.52 \pm 4.14^{\mathrm{a}}$ & $49.68 \pm 8.41^{\mathrm{a}}$ \\
\hline & 7 & - & $46.89 \pm 13.11^{\mathrm{a}}$ & $42.50 \pm 8.53^{\mathrm{a}}$ & $38.81 \pm 11.55^{\mathrm{a}}$ & $30.79 \pm 2.81^{\mathrm{a}, \mathrm{b}}$ & $38.58 \pm 3.69^{\mathrm{a}}$ & $48.86 \pm 10.05^{\mathrm{a}}$ \\
\hline \multirow{4}{*}{$\begin{array}{c}\text { Ulcer inhibition } \\
(\%)\end{array}$} & 1 & - & 0 & $10.01 \pm 8.44^{\mathrm{a}, \mathrm{b}}$ & $12.13 \pm 3.13^{\mathrm{a}, \mathrm{b}}$ & $27.82 \pm 2.50^{\mathrm{a}, \mathrm{b}, \mathrm{c}}$ & $13.39 \pm 7.75^{\mathrm{a}, \mathrm{b}}$ & $6.49 \pm 7.59^{\mathrm{a}, \mathrm{b}}$ \\
\hline & 3 & - & 0 & $8.10 \pm 6.87^{\mathrm{a}, \mathrm{b}}$ & $10.04 \pm 2.85^{\mathrm{a}, \mathrm{b}}$ & $29.17 \pm 2.44^{\mathrm{a}, \mathrm{b}, \mathrm{c}}$ & $5.64 \pm 6.02^{\mathrm{a}, \mathrm{b}}$ & $3.29 \pm 1.46^{\mathrm{a}, \mathrm{b}}$ \\
\hline & 5 & - & $13.34 \pm 9.69^{\mathrm{a}}$ & $26.76 \pm 7.01^{\mathrm{a}}$ & $32.14 \pm 8.62^{\mathrm{a}, \mathrm{b}}$ & $39.06 \pm 3.33^{\mathrm{a}, \mathrm{b}}$ & $37.72 \pm 7.15^{\mathrm{a}, \mathrm{b}}$ & $25.48 \pm 7.50^{\mathrm{a}}$ \\
\hline & 7 & - & $29.67 \pm 11.34^{\mathrm{a}}$ & $36.25 \pm 3.87^{\mathrm{a}}$ & $41.79 \pm 6.04^{\mathrm{a}}$ & $53.82 \pm 8.24^{\mathrm{a}, \mathrm{b}, \mathrm{c}}$ & $42.13 \pm 5.47^{\mathrm{a}}$ & $26.71 \pm 7.07^{\mathrm{a}}$ \\
\hline \multirow{4}{*}{$\begin{array}{c}\text { Mucus } \\
\text { ( } \mu \text { gAlcian blue/g } \\
\text { wet stomach }\end{array}$} & 1 & $37.38 \pm 2.13^{\mathrm{b}, \mathrm{c}}$ & $19.89 \pm 0.52^{\mathrm{a}, \mathrm{c}}$ & $22.11 \pm 0.05^{\mathrm{a}, \mathrm{b}, \mathrm{c}}$ & $25.72 \pm 0.62^{\mathrm{a}, \mathrm{b}, \mathrm{c}}$ & $27.44 \pm 0.50^{\mathrm{a}, \mathrm{b}}$ & $27.45 \pm 0.04^{\mathrm{a}, \mathrm{b}}$ & $22.78 \pm 0.67^{\mathrm{a}, \mathrm{b}, \mathrm{c}}$ \\
\hline & 3 & $34.62 \pm 0.24^{\mathrm{b}, \mathrm{c}}$ & $10.38 \pm 1.89^{\mathrm{a}, \mathrm{c}}$ & $16.08 \pm 0.11^{\mathrm{a}, \mathrm{b}, \mathrm{c}}$ & $18.22 \pm 0.05^{\mathrm{a}, \mathrm{b}, \mathrm{c}}$ & $22.06 \pm 0.51^{\mathrm{a}, \mathrm{b}, \mathrm{c}}$ & $24.76 \pm 0.20^{\mathrm{a}, \mathrm{b}}$ & $21.04 \pm 0.26^{\mathrm{a}, \mathrm{b}, \mathrm{c}}$ \\
\hline & 5 & $35.95 \pm 1.77^{\mathrm{b}, \mathrm{c}}$ & $12.87 \pm 2.35^{\mathrm{a}, \mathrm{c}}$ & $24.97 \pm 0.35^{\mathrm{a}, \mathrm{b}}$ & $28.54 \pm 0.05^{\mathrm{a}, \mathrm{b}, \mathrm{c}}$ & $30.35 \pm 0.26^{\mathrm{a}, \mathrm{b}, \mathrm{c}}$ & $25.12 \pm 0.26^{\mathrm{a}, \mathrm{b}}$ & $25.08 \pm 0.51^{\mathrm{a}, \mathrm{b}}$ \\
\hline & 7 & $33.89 \pm 0.32^{\mathrm{b}, \mathrm{c}}$ & $15.73 \pm 0.24^{\mathrm{a}, \mathrm{c}}$ & $28.54 \pm 0.26^{\mathrm{a}, \mathrm{b}, \mathrm{c}}$ & $31.05 \pm 1.74^{\mathrm{a}, \mathrm{b}, \mathrm{c}}$ & $32.89 \pm 0.05^{\mathrm{a}, \mathrm{b}, \mathrm{c}}$ & $31.23 \pm 0.22^{\mathrm{a}, \mathrm{b}}$ & $31.08 \pm 2.82^{\mathrm{b}}$ \\
\hline \multirow{4}{*}{$\begin{array}{l}\text { Plasma MDA } \\
(\mathrm{nM} / \mathrm{mL})\end{array}$} & 1 & $2.64 \pm 0.04^{\mathrm{b}, \mathrm{c}}$ & $15.50 \pm 0.91^{\mathrm{a}, \mathrm{c}}$ & $13.84 \pm 0.39^{\mathrm{a}, \mathrm{b}, \mathrm{c}}$ & $6.14 \pm 0.44^{\mathrm{a}, \mathrm{b}, \mathrm{c}}$ & $2.68 \pm 0.33^{\mathrm{b}, \mathrm{c}}$ & $3.52 \pm 0.39^{\mathrm{a}, \mathrm{b}}$ & $6.12 \pm 0.26^{\mathrm{a}, \mathrm{b}, \mathrm{c}}$ \\
\hline & 3 & $2.65 \pm 0.50^{\mathrm{b}, \mathrm{c}}$ & $19.71 \pm 1.38^{\mathrm{a}, \mathrm{c}}$ & $14.33 \pm 0.59^{\mathrm{a}, \mathrm{b}, \mathrm{c}}$ & $11.88 \pm 0.65^{\mathrm{a}, \mathrm{b}, \mathrm{c}}$ & $3.38 \pm 0.45^{\mathrm{a}, \mathrm{b}}$ & $3.83 \pm 0.34^{\mathrm{a}, \mathrm{b}}$ & $8.96 \pm 0.68^{\mathrm{a}, \mathrm{b}, \mathrm{c}}$ \\
\hline & 5 & $2.66 \pm 0.24^{\mathrm{b}, \mathrm{c}}$ & $18.47 \pm 0.96^{\mathrm{a}, \mathrm{c}}$ & $10.89 \pm 0.59^{\mathrm{a}, \mathrm{b}, \mathrm{c}}$ & $8.12 \pm 0.62^{\mathrm{a}, \mathrm{b}, \mathrm{c}}$ & $3.43 \pm 0.35^{\mathrm{a}, \mathrm{b}}$ & $3.56 \pm 0.27^{\mathrm{a}, \mathrm{b}}$ & $7.88 \pm 1.55^{\mathrm{a}, \mathrm{b}, \mathrm{c}}$ \\
\hline & 7 & $2.62 \pm 0.02^{\mathrm{b}, \mathrm{c}}$ & $9.46 \pm 0.65^{\mathrm{a}, \mathrm{c}}$ & $7.45 \pm 1.69^{\mathrm{a}, \mathrm{c}}$ & $4.08 \pm 0.77^{\mathrm{a}, \mathrm{b}}$ & $3.32 \pm 0.55^{\mathrm{a}, \mathrm{b}}$ & $3.42 \pm 0.39^{\mathrm{a}, \mathrm{b}}$ & $4.04 \pm 0.79^{\mathrm{a}, \mathrm{b}}$ \\
\hline \multirow{4}{*}{$\begin{array}{c}\text { Tissue MDA } \\
\text { (nM/mg tissue) }\end{array}$} & 1 & $0.20 \pm 0.02^{\mathrm{b}, \mathrm{c}}$ & $5.91 \pm 0.30^{\mathrm{a}, \mathrm{c}}$ & $2.55 \pm 0.12^{\mathrm{a}, \mathrm{b}, \mathrm{c}}$ & $1.11 \pm 0.26^{\mathrm{a}, \mathrm{b}, \mathrm{c}}$ & $0.24 \pm 0.02^{\mathrm{b}, \mathrm{c}}$ & $0.44 \pm 0.08^{\mathrm{a}, \mathrm{b}}$ & $0.52 \pm 0.21^{\mathrm{a}, \mathrm{b}}$ \\
\hline & 3 & $0.20 \pm 0.08^{\mathrm{b}, \mathrm{c}}$ & $7.19 \pm 0.27^{\mathrm{a}, \mathrm{c}}$ & $3.96 \pm 0.24^{\mathrm{a}, \mathrm{b}, \mathrm{c}}$ & $2.09 \pm 0.65^{\mathrm{a}, \mathrm{b}, \mathrm{c}}$ & $0.72 \pm 0.65^{\mathrm{a}, \mathrm{b}}$ & $1.18 \pm 0.08^{\mathrm{a}, \mathrm{b}}$ & $1.28 \pm 0.59^{\mathrm{a}, \mathrm{b}}$ \\
\hline & 5 & $0.20 \pm 0.04^{\mathrm{b}, \mathrm{c}}$ & $2.21 \pm 0.06^{\mathrm{a}, \mathrm{c}}$ & $1.68 \pm 0.83^{\mathrm{a}, \mathrm{c}}$ & $1.43 \pm 0.02^{\mathrm{a}, \mathrm{b}, \mathrm{c}}$ & $0.25 \pm 0.14^{b, c}$ & $0.69 \pm 0.18^{\mathrm{a}, \mathrm{b}}$ & $1.03 \pm 0.02^{\mathrm{a}, \mathrm{b}, \mathrm{c}}$ \\
\hline & 7 & $0.20 \pm 0.02^{\mathrm{b}}$ & $1.76 \pm 0.02^{\mathrm{a}, \mathrm{c}}$ & $0.88 \pm 0.24^{\mathrm{a}, \mathrm{b}, \mathrm{c}}$ & $0.39 \pm 0.02^{\mathrm{a}, \mathrm{b}, \mathrm{c}}$ & $0.20 \pm 0.04^{\mathrm{b}}$ & $0.24 \pm 0.02^{\mathrm{b}}$ & $0.26 \pm 0.02^{\mathrm{a}, \mathrm{b}}$ \\
\hline
\end{tabular}


http://wjst.wu.ac.th

\begin{tabular}{|c|c|c|c|c|c|c|c|c|}
\hline Parameter & Day & Group 1 & Group 2 & Group 3 & Group 4 & Group 5 & Group 6 & Group 7 \\
\hline \multirow{4}{*}{$\begin{array}{c}\text { GSSG } \\
\text { (ng/mgProtein) }\end{array}$} & 1 & $0.87 \pm 0.01^{\mathrm{b}, \mathrm{c}}$ & $1.07 \pm 0.04^{\mathrm{a}}$ & $1.01 \pm 0.04^{\mathrm{a}, \mathrm{b}, \mathrm{c}}$ & $0.95 \pm 0.01^{\mathrm{a}, \mathrm{b}, \mathrm{c}}$ & $0.89 \pm 0.20^{\mathrm{a}, \mathrm{b}, \mathrm{c}}$ & $1.05 \pm 0.03^{\mathrm{a}}$ & $0.93 \pm 0.01^{\mathrm{a}, \mathrm{b}, \mathrm{c}}$ \\
\hline & 3 & $0.88 \pm 0.01^{\mathrm{b}, \mathrm{c}}$ & $1.16 \pm 0.02^{\mathrm{a}, \mathrm{c}}$ & $1.07 \pm 0.02^{\mathrm{a}, \mathrm{b}}$ & $1.04 \pm 0.11^{\mathrm{a}, \mathrm{b}}$ & $0.92 \pm 0.15^{\mathrm{a}, \mathrm{b}, \mathrm{c}}$ & $1.08 \pm 0.05^{\mathrm{a}, \mathrm{b}}$ & $1.16 \pm 0.22^{\mathrm{a}, \mathrm{c}}$ \\
\hline & 5 & $0.92 \pm 0.02^{\mathrm{b}, \mathrm{c}}$ & $1.14 \pm 0.02^{\mathrm{a}, \mathrm{c}}$ & $1.03 \pm 0.04^{\mathrm{a}, \mathrm{b}, \mathrm{c}}$ & $1.02 \pm 0.06^{\mathrm{a}, \mathrm{b}, \mathrm{c}}$ & $0.91 \pm 0.05^{\mathrm{a}, \mathrm{b}}$ & $0.90 \pm 0.04^{\mathrm{b}}$ & $1.14 \pm 0.32^{\mathrm{a}, \mathrm{c}}$ \\
\hline & 7 & $0.88 \pm 0.03^{\mathrm{b}, \mathrm{c}}$ & $1.09 \pm 0.01^{\mathrm{a}}$ & $0.96 \pm 0.03^{\mathrm{a}, \mathrm{b}}$ & $0.92 \pm 0.02^{\mathrm{a}, \mathrm{b}}$ & $0.89 \pm 0.13^{\mathrm{b}}$ & $0.99 \pm 0.14^{\mathrm{b}}$ & $1.09 \pm 0.41^{\mathrm{a}}$ \\
\hline \multirow{4}{*}{$\begin{array}{c}\text { GPx } \\
\text { (U/gProtein) }\end{array}$} & 1 & $2.87 \pm 0.09^{\mathrm{b}, \mathrm{c}}$ & $0.51 \pm 0.05^{\mathrm{a}, \mathrm{c}}$ & $1.15 \pm 0.04^{\mathrm{a}, \mathrm{b}}$ & $1.46 \pm 0.10^{\mathrm{a}, \mathrm{b}}$ & $2.92 \pm 0.19^{\mathrm{b}, \mathrm{c}}$ & $1.21 \pm 0.26^{\mathrm{a}, \mathrm{b}}$ & $1.07 \pm 0.21^{\mathrm{a}, \mathrm{b}}$ \\
\hline & 3 & $2.78 \pm 0.19^{\mathrm{b}, \mathrm{c}}$ & $0.41 \pm 0.06^{\mathrm{a}, \mathrm{c}}$ & $0.69 \pm 0.09^{\mathrm{a}, \mathrm{b}, \mathrm{c}}$ & $1.32 \pm 0.04^{\mathrm{a}, \mathrm{b}, \mathrm{c}}$ & $2.40 \pm 0.07^{\mathrm{a}, \mathrm{b}, \mathrm{c}}$ & $0.89 \pm 0.05^{\mathrm{a}, \mathrm{b}}$ & $0.82 \pm 0.03^{\mathrm{a}, \mathrm{b}, \mathrm{c}}$ \\
\hline & 5 & $2.82 \pm 0.32^{\mathrm{b}, \mathrm{c}}$ & $0.70 \pm 0.33^{\mathrm{a}, \mathrm{c}}$ & $0.78 \pm 0.09^{\mathrm{a}, \mathrm{c}}$ & $1.36 \pm 0.52^{\mathrm{a}, \mathrm{b}, \mathrm{c}}$ & $2.53 \pm 0.06^{\mathrm{b}, \mathrm{c}}$ & $0.92 \pm 0.02^{\mathrm{a}, \mathrm{b}}$ & $0.87 \pm 0.07^{\mathrm{a}, \mathrm{c}}$ \\
\hline & 7 & $2.82 \pm 0.43^{\mathrm{b}, \mathrm{c}}$ & $0.75 \pm 0.28^{\mathrm{a}, \mathrm{c}}$ & $0.81 \pm 0.05^{\mathrm{a}, \mathrm{c}}$ & $1.51 \pm 0.37^{\mathrm{a}, \mathrm{b}, \mathrm{c}}$ & $2.59 \pm 0.07^{\mathrm{b}, \mathrm{c}}$ & $1.08 \pm 0.03^{\mathrm{a}, \mathrm{b}}$ & $0.93 \pm 0.32^{\mathrm{a}, \mathrm{b}, \mathrm{c}}$ \\
\hline \multirow{4}{*}{$\begin{array}{l}\text { Nitrile Contents } \\
\text { (nM/mgProtein) }\end{array}$} & 1 & $0.40 \pm 0.07^{b, c}$ & $1.34 \pm 0.31^{\mathrm{a}, \mathrm{c}}$ & $1.06 \pm 0.26^{\mathrm{a}, \mathrm{c}}$ & $0.83 \pm 0.10^{\mathrm{a}, \mathrm{b}}$ & $0.72 \pm 0.05^{\mathrm{a}, \mathrm{b}, \mathrm{c}}$ & $0.86 \pm 0.13^{\mathrm{a}, \mathrm{b}}$ & $0.92 \pm 0.22^{\mathrm{a}, \mathrm{b}}$ \\
\hline & 3 & $0.35 \pm 0.08^{\mathrm{b}, \mathrm{c}}$ & $2.48 \pm 0.06^{\mathrm{a}, \mathrm{c}}$ & $1.43 \pm 0.35^{\mathrm{a}, \mathrm{b}}$ & $1.01 \pm 0.06^{\mathrm{a}, \mathrm{b}, \mathrm{c}}$ & $0.91 \pm 0.12^{\mathrm{a}, \mathrm{b}, \mathrm{c}}$ & $1.51 \pm 0.49^{\mathrm{a}, \mathrm{b}}$ & $1.70 \pm 0.30^{\mathrm{a}, \mathrm{b}}$ \\
\hline & 5 & $0.30 \pm 0.07^{\mathrm{b}, \mathrm{c}}$ & $3.16 \pm 0.42^{\mathrm{a}}$ & $2.05 \pm 0.23^{\mathrm{a}, \mathrm{b}}$ & $1.53 \pm 0.11^{\mathrm{a}, \mathrm{b}, \mathrm{c}}$ & $1.21 \pm 0.40^{\mathrm{a}, \mathrm{b}, \mathrm{c}}$ & $2.46 \pm 0.85^{\mathrm{a}}$ & $2.29 \pm 0.46^{\mathrm{a}, \mathrm{b}}$ \\
\hline & 7 & $0.26 \pm 0.09^{\mathrm{b}, \mathrm{c}}$ & $1.99 \pm 0.33^{\mathrm{a}, \mathrm{c}}$ & $0.66 \pm 0.05^{\mathrm{a}, \mathrm{b}, \mathrm{c}}$ & $0.60 \pm 0.06^{\mathrm{a}, \mathrm{b}, \mathrm{c}}$ & $0.47 \pm 0.09^{\mathrm{a}, \mathrm{b}, \mathrm{c}}$ & $1.26 \pm 0.17^{\mathrm{a}, \mathrm{b}}$ & $1.78 \pm 0.29^{\mathrm{a}, \mathrm{c}}$ \\
\hline \multirow{4}{*}{$\begin{array}{l}\text { Plasma TNF- } \alpha \\
\quad(\mathrm{pg} / \mathrm{mL})\end{array}$} & 1 & $1.75 \pm 0.08^{\mathrm{b}}$ & $1.98 \pm 0.01^{\mathrm{a}, \mathrm{c}}$ & $1.80 \pm 0.01^{\mathrm{b}, \mathrm{c}}$ & $1.77 \pm 0.01^{\mathrm{b}}$ & $1.58 \pm 0.01^{\mathrm{a}, \mathrm{b}, \mathrm{c}}$ & $1.70 \pm 0.01^{\mathrm{b}}$ & $1.89 \pm 0.01^{\mathrm{a}, \mathrm{b}, \mathrm{c}}$ \\
\hline & 3 & $1.77 \pm 0.06^{\mathrm{b}}$ & $2.43 \pm 0.07^{\mathrm{a}, \mathrm{c}}$ & $1.88 \pm 0.02^{\mathrm{a}, \mathrm{b}}$ & $1.82 \pm 0.03^{\mathrm{b}}$ & $1.76 \pm 0.01^{\mathrm{b}, \mathrm{c}}$ & $1.84 \pm 0.04^{\mathrm{b}}$ & $1.92 \pm 0.03^{\mathrm{a}, \mathrm{b}, \mathrm{c}}$ \\
\hline & 5 & $1.77 \pm 0.06^{\mathrm{b}}$ & $2.15 \pm 0.10^{\mathrm{a}, \mathrm{c}}$ & $1.85 \pm 0.04^{\mathrm{a}, \mathrm{b}}$ & $1.76 \pm 0.04^{\mathrm{b}}$ & $1.68 \pm 0.05^{\mathrm{b}}$ & $1.78 \pm 0.05^{\mathrm{b}}$ & $1.89 \pm 0.02^{\mathrm{a}, \mathrm{b}, \mathrm{c}}$ \\
\hline & 7 & $1.76 \pm 0.09^{\mathrm{b}}$ & $2.00 \pm 0.01^{\mathrm{a}, \mathrm{c}}$ & $1.81 \pm 0.01^{\mathrm{a}, \mathrm{b}, \mathrm{c}}$ & $1.77 \pm 0.01^{\mathrm{b}, \mathrm{c}}$ & $1.62 \pm 0.01^{\mathrm{a}, \mathrm{b}, \mathrm{c}}$ & $1.69 \pm 0.01^{\mathrm{b}}$ & $1.90 \pm 0.01^{\mathrm{a}, \mathrm{b}, \mathrm{c}}$ \\
\hline
\end{tabular}

${ }^{\mathrm{a}} P<0.05$ compared with normal mice group (Group 1), ${ }^{\mathrm{b}} P<0.05$ when compared with indomethacin treated group (Group 2) and ${ }^{\mathrm{c}} P<0.05$ when compared with omeprazole treated group (Group 6) at the same day of ulceration.

NSAIDs induced gastric damage is the major side effect associated with usage of this drug. Although the mechanism of NSAID induced gastropathy is generally believed to be related to the ability of these agents to inhibit gastric prostaglandin generation [27], there is a great deal of evidence to suggest that neutrophils are important in the pathogenesis of the gastric damage induced by NSAIDs [28]. Activated neutrophils are a major source of ROS production. On the other hand, organisms have enzymatic and non-enzymatic defenses, including GSH and GPx against the ROS-induced lipid peroxidation [29]. In this experiment results showed that indomethacin markedly increased MDA, an index of lipid peroxidation, accompanied by an increase of GSSG and decreased of GPx, all of which are endogenous antioxidants. These results support an imperative role for oxidative stress in the pathogenesis of indomethacin induced gastric ulcer. Nevertheless, treatment with SCC results in significant increase in the activities of GPx, as well as a decrease of GSSG and MDA formation compared to indomethacin treated mice at the same day, reflecting its antioxidant potential.

The mechanism which underlie SCC effect of oxidative stress in indomethacin induced gastric ulcer could be attributed to the direct antioxidant and free radical scavenging activity of SCC or indirectly due to augmentation of intracellulas GSSG and GPx in mice gastric tissues, all of which can scavenge superoxide, hydrogen peroxide, hydroxyl and lipid peroxyl radicals, and attenuate damages to the tissue. However, after day 5 of ulceration, ulcer-autohealing is processing even in indomethacin treated group and gastric tissue are recovery, thus treatment with SCC and SCF can enhancing this healing process as well as within 7 days of ulceration.

NO and ROS exert multiple modulating effects on inflammation and play key roles in the regulation of immune responses. In general, the neuronal and endothelial nitric oxide synthase (nNOS and eNOS) isoforms produce low amounts of NO [30]. In contrast, the inducible form of NOS (iNOS) produces NO in higher quantities. Ulcerogenic dose of indomethacin was a 12-fold increase in gastric epithelial expression of iNOS activity compared with controls [31], and this increase was positively correlated with damage to the epithelium. Therefore, these results were shown the high amount of NO production after 
day 1 to day 5 of ulceration, thus iNOS generated NO is involved in gastric damage induced by indomethacin, However, the role of NO in granulocyte infiltration induced by indomethacin can be suggest that small amounts of NO released by cNOS (constitutive NOS) are sufficient to down-regulate indomethacin induced gastric granulocyte infiltration. iNOS generated NO is implicated in indomethacin induced gastric damage due to the course of an inflammatory response. Based on the results of our study, SCC was confirmed to have protective effects on indomethacin induced gastric ulceration in mice. The effect of SCC can be attributed to its reduction of oxidative damage, and its inhibitory effects on neutrophil infiltration as well as its anti-inflammatory effects in mice gastric tissue.

Plasma TNF- $\alpha$ of SCC in indomethacin induced gastric ulcer of co-treatment study

Plasma TNF- $\alpha$ in co-treatment study of normal mice was averaged from day $1-7$ of ulceration is about $1.784 \pm 0.01 \mathrm{pg} / \mathrm{ml}$. Treatment with indomethacin was significantly increased from day 1 to day 3 of ulceration compared to normal mice and the peak of plasma TNF- $\alpha$ was $2.428 \pm 0.07 \mathrm{pg} / \mathrm{ml}$ at the day 3 . Treatment of SCC at a concentration of $500 \mathrm{mg} / \mathrm{kgBW}$, plasma TNF- $\alpha$ was less increased when compared to normal group. In comparison with indomethacin treated mice at the same day of ulceration, SCC, omeprazole or vitamin $\mathrm{C}$ reduced the plasma TNF- $\alpha$ level from day 1 of experiment and were maintain the TNF- $\alpha$ level as normal mice until day 7 of ulceration (Table 1).

A proinflammatory role of $\mathrm{TNF}-\alpha$ has been demonstrated to influence the early stage of indomethacin induced small intestinal toxicity [32] and affect experimental NSAID induced gastropathy [33]. TNF- $\alpha$ is activate nuclear transcription factor-k $\beta(N F-k \beta)$, which lead to activation of transcription of various inflammatory genes [34], including iNOS. Increased plasma level of TNF- $\alpha$ has been reported to induce leukocyte adherence after indomethacin administration [35]. Therefore, TNF- $\alpha$, as well as the TNF- $\alpha$ dependent expression of adhesion molecules, can be considered a major player in the initiation, progression and persistence of indomethacin induced gastric mucosal inflammation and injury [24]. Similar to our results, TNF- $\alpha$ was increased from 1 - 3 days of ulceration after treated mice with indomethacin but after day 5 of ulceration, the suppression of TNF- $\alpha$ was facilitated ulcer healing. Our finding are confirm that SCC reduced the magnitude of the inflammatory process, triggered modulation of production of inflammatory mediators, including TNF- $\alpha$ [36] and were played a clear beneficial role in gastric defense mechanisms, favoring mucosal barrier efficient, through mucus secretion and reducing the inflammatory response.

\section{The expression of COX-1, COX-2 and iNOS of SCC in indomethacin induced gastric ulcer of co-treatment study}

Standard NSAIDs inhibit the enzymatic activity of both the constitutive (COX-1) and inducible (COX-2) isoforms without much selectivity. Our western blot studies of COX-1 were demonstrated in Figure 2A. COX-1 was revealed reduced expression on the day of ulcer induction as well as at peak ulceration (day 3). Treatment with SCC at $500 \mathrm{mg} / \mathrm{kgBW}$ for 3 days were increased the expression of the enzymes markedly, while omeprazole showed insignificant effect. However, the effects of SCC was better with COX-1 enzyme restoring its expression to normalcy after day 5 of ulceration. Overall, SCC was more efficient than omeprazole.

In tune with the above results, the COX-2 was significantly increased at day 3 of ulceration, the results were demonstrated in western blot and the ratio of COX-2 compared with $\beta$-actin internal control (Figure 2B). When considering both COX-1 and COX-2 expression results together, it is possible to speculate that nonselective COX inhibitors conventional NSAIDs such as indomethacin produce gastric hypermotility, followed by microvascular disturbances and neutrophil activation, and resulting in gastric damage. The gastric hypermotility and subsequent vascular disturbances are associated with a PG deficiency caused by COX-1-inhibition [37]. Therefore, the inhibition of COX-1 up-regulates the COX-2 expression by indomethacin administration. SCC was used as a pretreatment compound $1 \mathrm{~h}$ before indomethacin treated. SCC was increased the up-regulation of COX-1 enzyme resulting in downregulation to COX-2 expression when compared to indomethacin administration alone at day 3 of ulceration. Anyway, at day 5 and 7 the gastric ulceration were regenerated themselves, its make the 
constitutive COX-1 enzyme to restored and work as housekeeping role in the stomach and up-regulated COX-2 expression at the same day of ulceration.

The accumulating information indicates that the mucosal tissue injury is accompanied by upregulation in NOS, epithelial cell apoptosis and the induction of proinflammatory cytokines interleukin$1 \beta$ (IL-1 $\beta$ ) and TNF- $\alpha$ that trigger NF-k $\beta$ activation [38]. From previous results, an inflammation in gastric mucosa by indomethacin is accompanied by increased production of TNF- $\alpha$, which augments neutrophil-derived superoxide generation resulting to enhancing of NO level in plasma and increased the expression of iNOS in gastric tissue upon indomethacin administration at the peak of ulceration (day 3 ). However, NO is an antioxidant that regulates acid and gastric mucus release and mucosal blood flow and prevents peroxidation of membrane lipids [39]. Thus at day 5 of ulceration the high expression of iNOS was related with the adaptation processes of gastric tissue formation. SCC was strongly worked as antiinflammatory compounds by down-regulated iNOS expression from the first day of ulceration compared to indomethacin treated group.
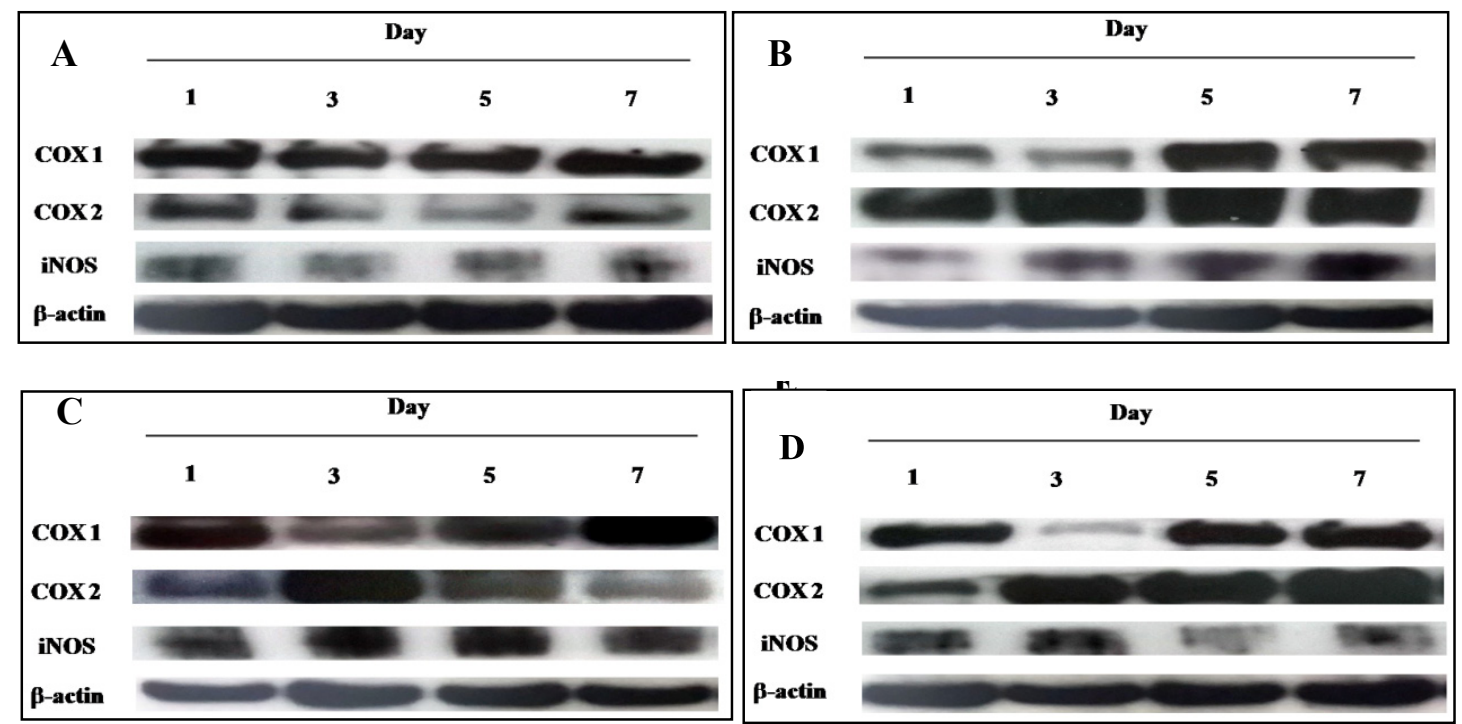

Figure 2 COX-1, COX-2 and iNOS expressed in co-treatment study at day 1, 3, 5 and 7. A: normal group, B: Indomethacin treated group, C: SCC at $500 \mathrm{mg} / \mathrm{kgBW}$ treated group and D: omeprazole at 100 $\mathrm{mg} / \mathrm{kgBW}$ treated group.

The immune staining of EGF of SCC in indomethacin induced gastric ulcer of co-treatment group

EGF receptor accelerates gastroduodenal ulcer healing by promoting intestinal epithelial restitution, an important early process in the re-epithelialization of ulcers [40]. Our studies clearly indicate that activation of EGF receptor is an important early event in gastric mucosal regeneration following acute injury [41]. As shown in Figure 3, EGF receptor was strongly expressed at day 5 and day 7 of ulceration in SCC treated group. 
http://wjst.wu.ac.th

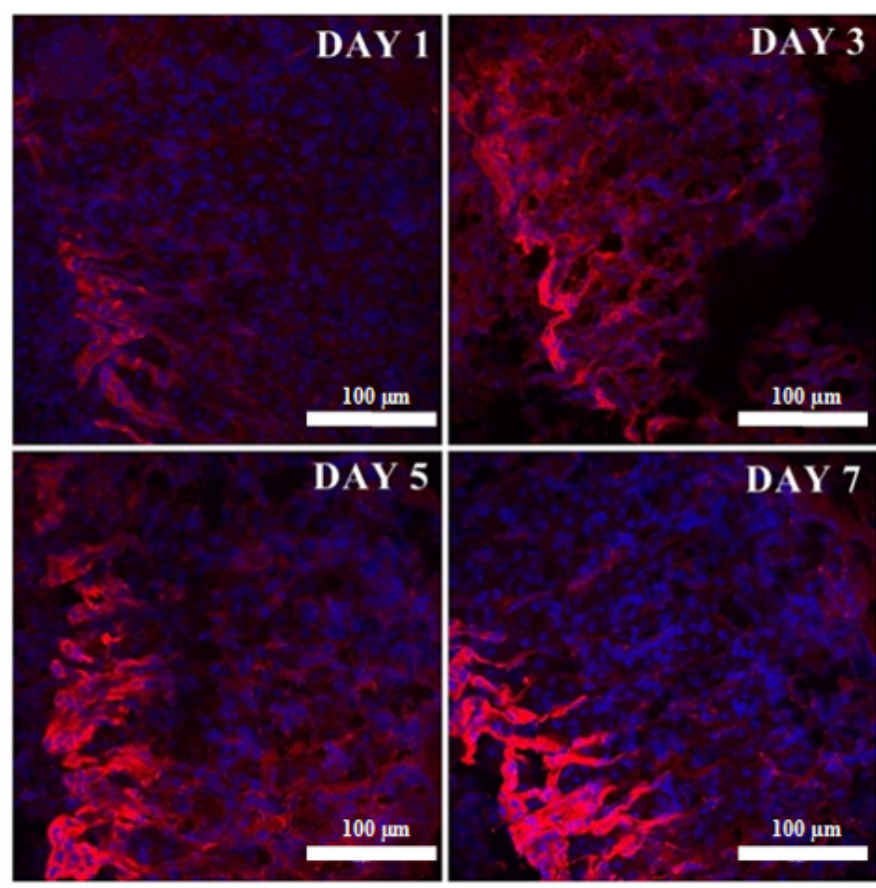

Figure 3 Immunohistograph of EGF receptor expressions in gastric tissues of SCC at $500 \mathrm{mg} / \mathrm{kgBW}$ in co-treatment study at day 1, 3, 5 and 7. Red color is showing EGF receptor expression and blue color are nuclei of gastric cells. White bars represent the scale of $100 \mu \mathrm{m}$.

\section{Conclusions}

Treated with indomethacin revealed mucosal haemorrhagic lesion and inhibited mucus content on mice. Redox imbalance was reflected by increased mucosal GSSG and NO content and decreased GPx activity along with elevated lipid peroxides. SCC caused discernible decreases in indomethacin induced gastric lesion and lipid peroxide content. In addition of co-treatment mice model, GSSG, GPx, NO levels and gastric wall mucus were restored. Indomethacin induced inflammatory by activated iNOS and TNF- $\alpha$ pro-inflammatory cytokines to release large amount of ROS/RNS. Co-treatment with SCC ameliorated TNF- $\alpha$ level and iNOS expression led to decrease the amount ROS/RNS. In a term of drug usage, indomethacin was used as non-selective inhibitor of COX enzyme which inhibited the expression of COX-1 and up-regulated COX-2 expression which may involvement of iNOS activation in this study. In co-treatment mice model, the investigation was continue from day 1 to day 7 of ulceration. The ulceration was peak at day 3 and after that a genetically programmed repair process (ulcer healing) is developed, resulting in the stage of scar formation even in indomethacin treated group. The major of early reepithelialization of gastric ulcer was depended on an activated of the EGF receptor. Our results on the increased in number of EGF receptor expressing cells at day 5 and day 7 of SCC treatment over that of the first day of ulceration, EGF receptor was expressed in the ulcer margin, indicating the importance of EGF receptor in ulcer healing. Thus, SCC might contribute to their healing activity via increasing the levels of mucin and activated the growth factor receptor as an angiogenesis activity. 
http://wjst.wu.ac.th

\section{Acknowledgements}

This work was supported by Walailak University Fund and the authors express thanks to the Research Excellence Center for Innovation and Health Product (RECIHP) and School of Allied Health Sciences, Walailak University, for providing all the facilities to conduct this work.

\section{References}

[1] M Tarique, HH Siddiqui, M Khushtar and MA Rahman. Protective effect of hydro-alcoholic extract of Ruta graveolens Linn. Leaves on indomethacin and pylorus ligation-induced gastric ulcer in rats. J. Ayurveda Integr. Med. 2016; 7, 38-43.

[2] K Ramakrishnan and RC Salinas. Peptic ulcer disease. Am. Fam. Phys. 2007; 76, 1005-12.

[3] T Ihamäki, K Varis and M Siurala. Morphological, functional and immunological state of the gastric mucosa in gastric carcinoma families. Comparison with a computer-matched family sample. Scand. J. Gastroenterol. 1979; 14, 801-12.

[4] C Sostres, CJ Gargallo and A Lanas. Nonsteroidal anti-inflammatory drugs and upper and lower gastrointestinal mucosal damage. Arthritis Res. Ther. 2013; 2013, S3.

[5] Z Halicia, B Polatb, E Cadircia, A Topcuc, E Karakusd, D Kosea, A Albayraka and Y Bayir. Inhibiting renin angiotensin system in rate limiting step by aliskiren as a new approach for preventing indomethacin induced gastric ulcers. Chem. Biol. Interact. 2016; 258, 266-75.

[6] G Singh. Gastrointestine complications of prescription and over-the-counter nonsteroidal antiinflammatory drugs: A view from the ARAMIS database. Am. J. Ther. 2000; 7, 115-21.

[7] M Boyacioglu, C Kum, S Sekkin, HS Yalinkilinc, H Avci, ET Epikmen and U Karademir. The effects of lycopene on DNA damage and oxidative stress on indomethacin-induced gastric ulcer in rats. Clin. Nutr. 2016; 35, 428-35.

[8] DE Furst, RW Ulrich and S Prakash. Nonsteroidal Anti-inflammatory Drugs, Disease-modifying Antirheumatic Drugs, Nonopioid Analgesics and Drugs used in Gout. In: BG Katzung, SB Masters and AJ Trevor (Eds.). Basic and Clinical Pharmacology. 12 ${ }^{\text {nd }}$ eds. McGraw Hill, USA, 2012.

[9] MA Morsy and MA El-Moselhy. Mechanisms of the protective effects of curcumin against indomethacin-induced gastric ulcer in rats. Pharmacology 2013; 91, 267-74.

[10] AA Asmari, SA Omani, MA Otaibi, AA Abdulaaly, I Elfaki and KA Yahya. Gastroprotective effect of minocycline in experimentally induced gastric ulcers in rats. Int. J. Clin. Exp. Med. 2014; 7, 58696.

[11] WIE Hinojosa, MA Quiroz, IR Alvarez, PE Castaneda, ML Villarreal and AC Taketa. AntiHelicobacter pylori, gastroprotective, anti-inflammatory, and cytotoxic activities of methanolic extracts of five different populations of Hippocratea celastroides collected in Mexico. $J$. Ethnopharmacol. 2014; 155, 1156-63.

[12] G Baldissera, NDM Sperotto, HT Rosa, JG Henn, VF Pere, DJ Moura, R Roehrs, ELG Denardin, PD Lago, RB Nunes and J Saffi. Effects of crude hydroalcoholic extract of Syzygium cumini (L.) Skeels leaves and continuous aerobic training in rats with diabetes induced by a high-fat diet and low doses of streptozotocin. J. Ethnopharmacol. 2016; 194, 1012-21.

[13] L Chanudom and J Tangpong. Scavenging activities and protective effects of Syzygium cumini (L.) Skeels on $\mathrm{H}_{2} \mathrm{O}_{2}$ induced oxidative stress in normal human peripheral blood mononuclear cells. $J$. Health Res. 2015; 29, 315-22.

[14] L Chanudom, P Bhoopong, R Khwanchuea and J Tangpong. Antioxidant and antimicrobial activities of aqueous \& ethanol crude extracts of 13 Thai traditional plants. Int. J. Curr. Microbial App. Sci. 2014; 3, 549-58.

[15] L Chanudom and J Tangpong. Anti-inflammation property of Syzygium cumini (L.) Skeels on indomethacin induced acute gastric ulceration. Gastroenterol. Res. Pract. 2015; 2015, 343642.

[16] M Ayyanar and P Subash-Babu. Syzygium cumini (L.) Skeels: A review of its phytochemical constituents and traditional used. Asian Pac. J. Trop. Biomed. 2012; 2. 240-6. 
http://wjst.wu.ac.th

[17] RSB Eshwarappa, RS Iyer, SR Subbaramaiah, RS Richard and BL Dhananjaya. Antiuoxidant activity of Syzygium cumini leaf gall extracts. Bioimpacts 2014; 4. 101-7.

[18] G Bonfanti, PR Bitencourt, KS Bona, PS Silva, LB Jantsch, AS Pigatto, A Boligon, ML Athyde, TL Gonealves and MB Moretto. Syzygium jumbos and Solanum guaraniticum show similar antioxidant properties but induced different enzymatic activities in the brain of rats. Molecules 2013; 18. 917994.

[19] SJ Corne, SM Morrissey and RJ Woods. A method for the quantitative estimation of gastric barrier mucus. J. Physiol. 1974; 242, 116-17.

[20] M Uchiyama and M Mihara. Determination of malonaldehyde precursor in tissues by thiobarbituric acid test. Anal. Biochem. 1978; 86, 271-8.

[21] RM Rolland. A review of chemically-induced alterations in thyroid and vitamin A status from field studies of wildlife and fish. J. Wildlife Dis. 2000; 36, 615-35.

[22] OH Lowry, J Nira, A Rosebrough, F Lewis and JR Rose. Folin phenol reagent protein measurement. J. Biol. Chem. 1951; 193, 265-75.

[23] KM Miranda, MG Espey and DA Wink. A rapid, simple spectrophotometric method for simultaneous detection of nitrate and nitrite. Nitric Oxide 2001; 5, 62-71.

[24] SK Yadav, B Adhikary, S Chand, B Maitty, SK Bandyopadhyay and S Chattopadhyay. Molecular mechanism of indomethacin-indued gastropathy. Free Radic. Biol. Med. 2012; 52, 1175-87.

[25] D Banerjee, K Ajay, RK Bauri, SK Guha, Bandyopadhyay and C Subrata. Healing properties of malabaricone $\mathrm{B}$ and malabaricone $\mathrm{C}$, against indomethacin-induced gastric ulceration and mechanism of action. Eur. J. Pharmacol. 2008; 578. 300-12.

[26] O Dormond, M Bezzi, A Mariotti and AS Ruegg. Prostaglandin E2 promotes integrin $\alpha \mathrm{V} \beta 3$ dependent endothelial cell adhesion, rac-activation, and spreading through cAMP/PKA-dependent signaling. J. Biol. Chem. 2002; 277, 45838-46.

[27] L Laine. Stratifying the risk of clinical upper GI events in NSAID users: Results from a doubleblind outcomes study. Gastroenterology 2001; 120, A552.

[28] MHLP Souza, H Paula Lemos, RB Oliveira and FQ Cunha. Gastric damage and granulocyte infiltration induced by indomethacin in tumor necrosis factor receptor 1 (TNF-R1) or inducible nitric oxide synthase (iNOS) deficient mice. Gut 2012; 53, 791-6.

[29] JM Mates, JM Segura, C Perez-Gomez, R Rosado, L Olalla, M Blanca and F Sanchez. Antioxidant enzymatic activities in human blood cells after an allergic reaction to pollen or house dust mite. Blood Cell Mol. Dis. 1999; 25, 103-12.

[30] JL Wallace and MJ Miller. Nitric oxide in mucosal defense: A little goes a long way. Gastroenterology 2000; 119, 512-20.

[31] J Piotrowski, A Slomiany and BL Slomiany. Activation of apoptotic caspase-3 and nitric oxide synthase-2 in gastric mucosal injury induced by indomethacin. Scand. J. Gastroenterol. 1999; 34. 129-34.

[32] V Bertrand, R Guimband, M Tulliez, C Mauprivez, P Sogni, D Couturier, JP Giroud, S Chanssade and ML Chauvelot. Increase in tumor necrosis factor- $\alpha$ production linked to toxicity of indomethacin in the rat small intestine. Br. J. Pharmacol. 1998; 124, 1385-94.

[33] L Santucci, S Fiorucci, M Giansanti, PM Bounori, FM DiMatteo and A Morelli. Pentoxifylline prevents indomethacin induced acute gastric mucosal damage in rats: Role of tumor necrosis factor alpha. Gut 1994; 35, 909-15.

[34] MB Grisham, KP Pavlick, FS Laroux, J Hoffnan, S Bharwani and RE Wolf. Nitric oxide and Chronic Gut Inflammation: Controversies in inflammatory bowel disease. J. Investig. Med. 2002; 50, 272-83.

[35] CB Appleyard, DM, McCafferty, AW Tigley, MG Swain and JL Wallace. Tumor necrosis factor mediation of NSAID-induced gastric damage: Role of leukocyte adherence. Am. J. Physiol. 1996; 270, G42-G48. 
http://wjst.wu.ac.th

[36] MS Leite, P Pacheco, RN Gomes, AT Guedes, HC Castro-Faria-Neto and PT Bozza. Mechanism of increased survival after lipopolysaccharide-induced endotoxic shock in mice consuming olive oilenriched diet. Shock 2005; 23, 173-8.

[37] A Tanaka, H Araki, Y Komoike, S Hase and K Takeuchi. Inhibition of COX-1 and COX-2 is required for development of gastric damage in response to nonsteroidal anti-inflammatory drugs. $J$. Physiol. Paris. 2001; 95. 21-7.

[38] BL Slomiany and A Slomiany. Role of ERK and p38 mitogen activated protein kinase cascades in gastric mucosal inflammatory responses to H. pylori lipopolysaccharide. Int. Union Biochem. Mol. Biol. Life 2001; 51, 315-20.

[39] B Polat, H Suleyman and HH Alp. Adaptation of rat gastric tissue against indomethacin toxicity. Chem. Biol. Interact. 2010; 186, 82-9.

[40] M Gennett, MT Myhre, S Abraham and LJ Egan. Metalloprotease disintegrin-mediated ectodomain shedding of EGFR ligands promotes intestinal epithelial restitution. Am. J. Physiol. Gastrointest Liver Physiol. 2004; 287, G1213-G1219.

[41] A Tarnawski, J Stachura, T Durbin, IJ Sarfeh and H Gergely. Increased expression of epidermal growth factor receptor during gastric ulcer healing in rats. Gastroenterology 1992; 102, 695-8. 